\title{
Women Empowerment Through Microfinance: Empirical Evidence from Ghana
}

\author{
Bismark Addai \\ School of Management and Economics, University of Electronic Science and Technology of China, Chengdu, P.R. China
}

\section{Email address:}

abismarks@hotmail.com

\section{To cite this article:}

Bismark Addai. Women Empowerment Through Microfinance: Empirical Evidence from Ghana. Journal of Finance and Accounting. Vol. 5, No. 1, 2017, pp. 1-11. doi: 10.11648/j.jfa.20170501.11

Received: September 4, 2016; Accepted: January 3, 2017; Published: January 13, 2017

\begin{abstract}
Microfinance programmes are currently promoted as a key strategy for simultaneously addressing both women empowerment and poverty alleviation in Ghana. However, there has been a hot debate on the potency of microfinance in empowering the Ghanaian women. Apparently, this research was conducted to analyse the impact of microfinance services on the economic and social empowerment of women in Ghana. A purposive non-probability sampling technique was utilized in a 500 sample-size selection of female microfinance customers from Ashanti, Greater Accra, Central, Eastern and Western Regions of Ghana (100 from each region). For this study, SPSS and STATA Statistical tools were used to analyze the data and the ordered probit model was used as the estimation model. Glaring in this study is a statistically significant positive relationship between microfinance and women empowerment, for both economic and social but such relationship is dependent on marital status and educational level of the women with age having no controlling effect. Nevertheless, it is also evident in this study that women encounter myriad problems in accessing microfinance services of which high interest rate is paramount. Recommendations have been given on how microfinance outreach programmes could be enriched especially among the rural women since enhanced microfinance accessibility could be a perfect tool to accelerate economic and social empowerment of women in Ghana.
\end{abstract}

Keywords: Microfinance, Economic, Social, Women Empowerment, Poverty Alleviation

\section{Introduction}

Micro financing has taken the pace particularly in developing and the under-developed countries for the last couple of decades and governments of these countries have designed and implemented many financial and economic policies particularly to enhance microfinance for its potential in simultaneously empowering women and alleviating poverty.

Economist, Professor Muhammad Yunus came up with the idea of microfinance which is now known as "The Grameen Model" in 1976 [1]. During a field trip to a relatively poor village in Bangladesh with his students, he lent a small amount of money to a group of women who were rural basket-weavers. The loan did not only to help the poor women to survive but also to create the spark of personal initiative and enterprise in the people, necessary to pull themselves out of poverty. Just two years after his field trip, he established the Grameen Bank, and introduced "Grameen
Model", which is now being considered as one of the most successful models in the microfinance industry $[1,2]$. This presupposes that microfinance originally emanated with the view to empowering women, no wonder it is sometimes called 'women finance'.

Cull et al. (2007) also affirm that the process started in 1970 's when generous subvention was required to run financial institutions serving poor women in low-income countries [3]. They further explain that a generous subvention was first given to the poor female basket weavers which served as a strong foundation upon which they earned income and saved to provide loans for themselves on rotational basis. The manifestation of the poor women that they can be reliable as bank customers is the supreme achievement of micro financing, a major factor that has contributed to the growth of microfinance [3].

Women empowerment is a global challenge because most women have been relegated to the back side and subjected under control of men as a result of unfair social, cultural and 
political structures in many parts of the world. About $70 \%$ percent of world's poor are women and about $65 \%$ percent of women in Ghana live in absolute poverty [4]. These poor women have no access to financial services from conventional banks for lack of collateral security. In the past, Ghanaian women were restricted to the kitchen whiles men schooled and as such women were not expected to influence the decision-making processes from domestic level to the national level [5]. In the family, men are still considered as heads of households which limit women in influencing allocation of domestic resources [6].

Policies to surmount the problems among women in Ghana have been linked to women empowerment and poverty alleviation. Many women empowerment programs have a micro-credit component, which has been extensively promoted as a way of enhancing microfinance to simultaneously address the issues of women empowerment and poverty alleviation [4]. The Government of Ghana (GoG) has promulgated several projects to enhance 'women finance' in order to empower Ghanaian women and some of those projects are: Financial sector improvement projects; Financial sector strategic plan (FNSSP); Rural Financial Services Project; United Nations Development Program (UNDP); The Social Investment Fund (SIF); Community Based Development Program (CBRDP); Rural Enterprise Project; Agricultural Services Investment Project (ASSIP).

Even though GoG has developed and implemented various policies and programs to enhance microfinance to simultaneously empower women and alleviate poverty, most women are still incapacitated and unwilling to take up certain positions and responsibilities like the men do coupled with their entanglement with poverty. There is has been a rising argument that microfinance does not foster women empowerment because loan given to women is controlled by men and also Microfinance Institutions (MFIs) are extorting money from poor women through very high interest rates just like the money lenders, and also lead to many women running away from their homes and villages after failure of repayment of loan installment avoiding their properties to be taken by MFIs [7-9]. On the contrary, researches conducted in developing countries like India, Tanzania, Ethiopia and Nigeria concluded that accessibility to microfinance services contributes to women empowerment [10-14]. Much attention has not been given to the impact of microfinance programs on women empowerment in Ghana and the debate on the potency of microfinance services to empower the Ghanaian women goes unabated. Consequently, this research is conducted to contribute to the debate on the impact of microfinance programs on the economic and social empowerment of women in Ghana.

\section{Research Objectives}

The general objective of the study is to examine the empowerment of women in Ghana through micro finance. The following specific objectives will be achieved in order to achieve the general objective of this research.

(1) To assess microfinance service accessibility among women
(2) To identify problems that women face in accessing microfinance services

(3) To examine the impact of microfinance on economic empowerment of women

(4) To assess the impact of microfinance on social empowerment of women

\section{Literature Review}

This section presents literature review on microfinance service and accessibility, women empowerment as well as impact of microfinance on women empowerment.

\subsection{Microfinance Services and Accessibility}

Microfinance Institutions (MFIs) provide similar products and services to their customers as formal sector financial institutions. The scale and method of delivery differ, but the fundamental services of savings, loans, and insurance are the same. Most efforts to formalize microfinance have focused on enterprise lending (loans for enterprise formation and development) which remain by far the dominant product offered by MFIs [15]. This, however, has slowly begun to change. Increasingly, currently MFIs have begun to offer additional products, such as savings, consumption or emergency loans, insurance, and business education [16,17]. Nourse (2001), in his review on the context and rise of microfinance products argues that there is the need for savings and insurance services for the poor and not just credit products [18]. Like many other countries, MFIs in Ghana offer three major services to their clients; micro-credit, micro-savings and micro-insurance and casually provides their clients with non-financial services such as business education and training [19].

Four main microfinance methodologies have been recognized in literature, namely: individual lending, group lending, credit unions to self-help organizations also known as Rotating Savings and Credit Associations (ROSCAs) [3]. Some MFIs start with one methodology and later on move or diversify to another methodology so that they do not exclude certain socio-economic categories of clients. In most rural areas in Ghana credit unions are still the solitary source of deposit and credit services, besides the informal financial market. Because credit unions have social as well as commercial objectives, they may have a key role to play in offering pro-poor financial services. However, the most widely used method of accessing microfinance in Ghana is the ROSCAs popularly known as "susu", an idea which already existed in Northern part of Ghana even before Muhammed Yunus discovered the idea of microfinance in Bangladesh in 1970s.

Accessibility to microfinance is explained as, the right to obtain or make use of or take advantage of microfinance (as services or membership) [20]. Accessibility to microfinance takes varying forms ranging from individual lending, group lending, credit unions to self-help organizations. Through the four basic methods clients are able to access microfinance services. The popularity of a method in one area greatly 
influences its usage. Microfinance clients in Ghana have the right to microfinance services through any of the four schemes. It is worth mentioning that, all clients have the same privilege irrespective of the method chosen whether through individual lending, group lending, credit unions or self-help organizations. In this study, women's accessibility to microfinance service is analysed in terms of major services women access from MFIs, how long they have accessed such services, number of times they have accessed such services and their views on how responsive their MFIs have been when the need arises.

On the other hand, prior researches have indicated that there exits inherent problems limiting women's accessibility to microfinance services [21, 22]. Paramount among those problems identified in literature are: high interest rate on loans; collateral required for loans and cumbersome service application procedures [23-26]. This study therefore goes further to analyse some problems that these women encounter in accessing microfinance services.

\subsection{Women Empowerment}

Mosedale (2005) states that if we want to see people empowered, it means we currently see them as being disempowered, disadvantaged by the way power relations shape their choices, opportunities and well-being [27]. The stimulus for empowerment as a process comes when something alters in a person's life that expands spaces. Kabeer (2005) establishes women empowerment as the processes by which women take control and ownership of their lives through expansion of their choices [28]. Women empowerment refers to the process by which women who have been denied the ability to make strategic life choices acquire such ability, where strategic choices are critical for people to live the lives they want.

Although MFIs cannot empower women directly, MFIs can help them through training and awareness-raising to challenge the existing norms, cultures and values which place them at a disadvantage in relation to men, and to help them have greater control over resources and their lives. By offering poor households access to formal or semi-formal financial services, microfinance has the potential to empower its clients in a variety of ways: providing women greater security and power, linking women with networks beyond their neighborhoods through group formation [11,29,30]. Microfinance services that foster group formation and selfmanagement by women have additional potential to empower women through exposure to new ideas, mutual support, fostering an identity beyond the family and the opportunity to cultivate leadership roles and responsibilities.

Contemporary studies on the impact of microfinance on women empowerment acknowledges five main dimensions of women empowerment resulting from their participation in microfinance programs: economic, social, political, legal and psychological empowerment of which economic and social empowerment are the most predominant [11, 31-37]. Therefore, this study concentrates on economic and social empowerment of women.
Economic empowerment of women is recognized as women's control, access to credit, contribution to family support and increased household ownership of properties and assets [38, 39]. Women's access to savings and credit gives them a greater economic role in decision making through their decision about savings and credit. Women control over decisions regarding credit and savings could benefit men through preventing leakage of household income to unproductive and harmful projects. Economic empowerment includes women's control, access to credit, contribution to family support and increased household ownership of properties and assets.

Social empowerment of women includes freedom of movement, lack of discrimination against daughters, commitment to educating daughters, participation in domestic decision making, freedom from violence [40, 41]. Through financial services, women have greater potential to increase their earnings, which fosters internal attitudes (selfreliance, self-confidence and self-worth) which can translate into external changes (greater bargaining power within the household and leadership in the community). Microfinance services that foster group formation and self-management by women have additional potential to empower women through exposure to new ideas, mutual support, fostering an identity beyond the family and the opportunity to cultivate leadership roles and responsibilities. Social empowerment includes freedom of movement, lack of discrimination against daughters, commitment to educating daughters, participation in domestic decision making, control over sexual relations, ability to make childbearing decisions, use contraception, control over spouse selection and marriage timing and freedom from violence.

\subsection{Empirical Evidence on the Impact of Microfinance on Women Empowerment}

Many evaluations of MFIs have shown that microfinance services have a positive impact on women empowerment and some of these works are reviews as follows. Kabeer (2001) used the index/indicator approach to examine the impact of microfinance accessibility on women empowerment in Tanzania and established that women's accessibility to microfinance services had significant effects on eight different dimensions of women's empowerment of which the paramount was economic empowerment [42]. The study also revealed that women's accessibility to microfinance was significant determinant of the magnitude of economic contributions reported by women; of the likelihood of an increase in asset holdings in their own names; of an increase in their exercise of purchasing power. However, the index/indicator approach only assigns numerical values (or arbitrary weights) to the ordinal measures that are generally qualitative responses and thus categorical in nature. In addition, assigning these values or weights is inappropriate and may also lead to loss of information and misleading conclusions since those weights are arbitrary generated by the researcher. It is in the light of this gaps in the methodology used by prior researchers such as Kabeer 
(2001) that this current study employs the use of the ordered probit model to estimate the impact of microfinance on women empowerment in Ghana whiles introducing women attributes such as age, education, mariatl status and occupation as control variables.

In India, Laha and Kuri (2014) conducted a study on how microfinance outreach programme contributes to women empowerment across countries with special emphasis on states in India [11]. In their study, they considered three such dimensions like economic, financial, and social empowerment to construct women empowerment index (IWE) and also constructed microfinance outreach Index (IMO). Broadly, their construction of women's empowerment index followed the same methodology as IMO. For each dimension (economic and social), the relative performance of the state in respect of national average was estimated. Then the relative performance of the state was divided by the share of the women households of the state to calculate relative share. The IMO and IWE estimates were then used to further estimate the relationship between the two variables. Their study established that states having higher level of microfinance programs are also the states with a relatively high level of economic empowerment of women. They also found that participants experience an increase in monthly income thus, concluded that an all-inclusive microfinance system would strengthen the process of financial inclusion in India and thereby would promote women's economic empowerment. However, their methodology only focused on merely establishing the relationship between microfinance outreach and women empowerment without paying attention to other women empowerment attributes such as age, occupation, marital status and educational background which may also have effect on such relationship existing between microfinance outreach and women empowerment. Consequently, this study uses the ordred probit model to estimate the relationship between microfinance accessibility and women empowerment by introducing four women empowerment attributes which may also influence the estimation as control variables: age, education, marital status and occupation.

A study by Khan and Noreen (2012) on the role of microfinance in empowerment of women in Pakistan finds that access to credit through microfinance organizations has a positive impact on social empowerment of women and also that loan utilization by the woman herself is of importance [43]. Khan and Noreen measured social empowerment by the construction of an index from indicators of child health, education, selection of spouse of children and leadership responsibility in the society. They specifically assessed the impact of microfinance accessibility on commitment of women to send their children to school and the ability to influence domestic decisions. They concluded that access to microfinance can empower women to commit themselves to children's education, become more confident, more assertive, more likely to take part in family and community decisions and better able to confront gender inequities.

\section{Research Methodology}

This section presents the underlying methodology adopted for this research including the research design and the estimation model.

\subsection{Research Design}

The population of the study was women customers of MFIs in Ghana. A purposive non-probability sampling technique was utilized in a 500 sample-size selection from female microfinance customers from Ashanti, Greater Accra, Central, Eastern and Western Regions of Ghana (100 from each region). The use of purposive non-probability sampling in this study is based on position of Neuman (2006) on sampling also emphasized by Zikmud (2002) that a nonprobability sampling technique is necessary when peculiar characteristic are required of the sample members [44, 45]. Again, the sample size is judgmental as the population is infinite because individual MFIs are not willing to disclose the number of their customers due to competition and other reasons.

Structured questionnaires were used to gather primary data from women sampled. The primary data were gathered in four different categories. The first category was data on the human attributes of the women engaged in this study, namely: age, educational background, marital status and occupation. The second category of primary data gathered in this study was on microfinance accessibility among these women: major services women access from MFIs, how long they have accessed such services, number of times they have accessed such services and their views on how responsive their MFIs have been when the need arises and the problems these women face in accessing microfinance. The third category of primary data was gathered on economic empowerment of women which involved data on variables such as: women's financial control, access to credit, contribution to family support and increased household ownership of properties and assets. The fourth category of data was gathered on the social empowerment of women which also included variables such as: commitment to educating daughters, participation in domestic decision making, ability to make childbearing decisions, control over spouse selection and marriage timing and freedom from violence.

Descriptive and the causal research designs were employed in this study based on explanation given by Hair et al. that causal research aims at showing that one variable causes or determines the values of other variables and descriptive research design is also appropriate when the research objectives include the determination of the degree to which marketing variables are related to actual marketing phenomena [46].

A quantitative research approach was utilised in this study because it ensures objectivity and avoids biases. Quantitative approach provided the means by which data were converted into discrete units to be compared to other units by using statistical analysis which is an essential part of quantitative research. 
STATA and SPSS Statistical tools were used for the analysis and the estimation of the model in this study. SPSS was used for the descriptive statistics whiles STATA was used for the ordred probit modeling.

\subsection{The Estimation Model}

In reality, any effort to quantify the effects of one variable on another without careful attention to the other factors affecting the latter could create serious statistical difficulties termed "omitted variables bias" which are usually unobservable. Alternatively, ordered response models, namely the ordered probit (OP) or logit (OL) models have increasingly been employed for modeling cause and effect relationships when it is recorded in multiple ordinal categories [47]. The OP model is especially appropriate to model women empowerment resulting from microfinance because, besides identifying statistically significant relationships between explanatory variables and a dependent variable, it also discerns unequal differences between ordinal classes in the dependent variable and also avoids assigning arbitrary values or weights [47].

The model, originally proposed by McKelvey and Zavoina (1975) as an alternative to the ordinary linear regression, is usually built around the idea of a latent underlying women empowerment tendency resulting from microfinance that determines the observed ordinal empowerment level [48]. The general specification is:

$$
\mathrm{z}_{i}=\beta X_{i}+\varepsilon_{i}
$$

where $\mathrm{z}_{i}$ denotes the latent women empowerment of respondent $i, \beta$ is the vector of parameters to be estimated, $X_{i}$ is the vector of observed non-random explanatory variables measuring the attributes of respondent $i$, and $\varepsilon_{i}$ is the random error term following standard normal distribution. Accordingly, the mean and the variance of $\varepsilon_{i}$ are normalized to zero and one, respectively. Since the dependent variable, $\mathrm{z}_{i}$ is unobserved, standard regression techniques cannot be applied to compute Equation (1). Assuming that high propensity to be empowered, denoted by $z_{i}$, is related to high level of observed empowerment also denoted by $y_{i}$. This relationship can be translated as follows:

$$
y_{i}=\left\{\begin{array}{c}
1, \text { if } \mathrm{z}_{i} \leq \mu_{1} \\
k, \text { if } \mu_{k-1}<\mathrm{z}_{i} \leq \mu_{k} \\
K, \text { if } \mathrm{z}_{i}>\mu_{k-1}
\end{array}\right.
$$

where $\mu=\left\{\mu_{1}, \ldots, \mu_{k}, \ldots, \mu_{k-1}\right\}$ are the threshold values for all empowerment levels that define $y_{i}$, corresponding to integer ordering, and $k$ is the highest ordered empowerment level. In turn, the probability that a respondent $i$ attains empowerment level $k$ is equal to the probability that the latent degree of empowerment, $z_{i}$ assumes a value between two fixed thresholds. In other words, given the value of $X_{i}$, the probability that the level of empowerment attained by a respondent $i$ belong to each empowerment level is:

$$
\left\{\begin{array}{l}
P(y=1)=\phi\left(-\beta X_{i}\right) \\
P(y=k)=\phi\left(\mu_{k-1}-\beta X_{i}\right)-\phi\left(\mu_{k-2}-\beta X_{i}\right) \\
P(y=K)=1-\phi\left(\mu_{k-1}-\beta X_{i}\right)
\end{array}\right.
$$

where $\phi$ is the cumulative normal distribution function. For estimation, Equation (3) can be written as (Washington et al., 2003):

$$
P(y=k)=\phi\left(\mu_{k}-\beta X_{i}\right)-\phi\left(\mu_{k+1}-\beta X_{i}\right)
$$

where $\mu_{k}$ and $\mu_{k+1}$ denote the lower and upper thresholds for the level of empowerment $k$, respectively. For all the probabilities to be positive, the thresholds values must satisfy the restriction $\mu_{1}<\ldots<\mu_{k}<\ldots<\mu_{k-1}$. Computation of these probabilities allows the understanding of the effect of individual estimated parameters. Indeed, a positive value of $\beta_{i}$ implies that an increase in $X_{i}$ will clearly generate the increase (respectively, decrease) of the probabilities of the highest (respectively, lowest) ordered empowerment levels. However, it is not obvious what affect a positive or negative $\beta_{i}$ will generate on the probabilities of the intermediate levels. For this reason, the computation of marginal effects for each level is necessary. These marginal effects provide the direction of the probability for each level as follows:

$$
P(y=k) / \partial X=\left[\phi\left(\mu_{k}-\beta X_{i}\right)-\phi\left(\mu_{k-1}-\beta X_{i}\right)\right] \beta
$$

In the specific case of a categorical variable, the computation of Equation (5) is not appropriate since it only makes sense if the variable is continuous. Instead, the probabilities that result when the variable changes from 0 to 1 , holding all other variables values at their means, should be compared. That is, for a categorical variable $X_{i}$, the corresponding marginal effect is

$$
X_{i}=P\left(y=k \mid X_{i}=1\right)-P\left(y=k \mid X_{i}=0\right)
$$

The thresholds $\mu$ are unknown parameters to be estimated jointly with the model parameters $\beta$. Here, both are estimated through the maximum likelihood method.

From the general specifications of the OP model, this study introduces three control variables: age, marital status and education in determining both economic and social empowerment of women resulting from microfinance accessibility with those demographic attributes as control variables. The general specifications are translated into the following equations in estimation of economic and social empowerment of women in Ghana from microfinance.

$$
\begin{gathered}
\mathrm{EE}^{*}=\beta_{1} \mathrm{MF}+\beta_{2} \text { Age }+\beta_{3} \text { Marital }+\beta_{4} \text { Education }+\varepsilon_{i} \\
\mathrm{SE}^{*}=\gamma_{1} M F+\gamma_{2} \text { Age }+\gamma_{3} \text { Marital }+\gamma_{4} \text { Education }+e_{i}
\end{gathered}
$$

and Marital $=\left\{\begin{array}{c}1=\text { Married } \\ 0=\text { Otherwise }\end{array}\right.$

Where $\mathrm{EE}^{*}$ and $\mathrm{SE}^{*}$ denote the latent economic and social empowerment of women respectively. $\beta_{1}, \beta_{2}, \beta_{3}, \beta_{4}, \gamma_{1}, \gamma_{2}$, $\gamma_{3}$, and $\gamma_{4}$ are the vectors of parameters to be estimated, MF is the vector of observed non-random explanatory variable Microfinance accessibility whiles Age, Marital Status and Education are also explanatory variables measuring the demographic attributes of the respondents, and $\varepsilon_{i}$ is the 
random error term following standard normal distribution. In equations (7) and (8), $E E^{*}$ and $S E^{*}$ are the unobserved dependent variables, MF is the independent variable whiles Age, Marital Status and Education are the control variables. For the control variables, marital status is a dummy variable: when marital status $=1$, the woman is married; when marital status $=0$, the woman is not married.

Since the dependent variables $\mathrm{EE}^{*}$ and $\mathrm{SE}^{*}$ are unobserved, standard regression techniques cannot be applied to compute Equations (7) and (8). We cannot observe EE* and $\mathrm{SE}^{*}$, we instead can only observe the categories of responses which are translated as follows:

$$
E S=\left\{\begin{array}{rrr}
1 & \text { if } & E S^{*} \leq u_{1} \\
2 & \text { if } & u_{1}<E S^{*} \leq u_{2} \\
3 & \text { if } & u_{2}<E S^{*} \leq u_{3} \\
4 & \text { if } & u_{3}<E S^{*} \leq u_{4} \\
5 \text { if } & E S *>u_{4}
\end{array}\right.
$$

Where ES represents categories of responses on Economic empowerment (EE) and Social empowerment $(\mathrm{EE})=(1,2,3$, 4, 5) for (Strongly Disagree, Disagree, Neutral, Agree, Strongly Agree). From equations (7) and (8), the ordered probit technique will use the observations on $E E$ ans $S E$, which are a form of censored data on $E E^{*}$ to estimate the parameter vectors $\beta_{1}, \beta_{2}, \beta_{3}, \beta_{4}, \gamma_{1}, \gamma_{2}, \gamma_{3}$, and $\gamma_{4}$.

\section{Data Analysis and Discussion of Results}

The following interpretations and discussions were based on the analysis and findings of the study.

\subsection{Demographic Data of Women Clients}

The human attributes of the women engaged in this study are presented in Table 1 below.

Table 1. Demographic characteristics of the sample.

\begin{tabular}{lllll}
\hline Variables & Type & Frequency & Percentage & $\begin{array}{l}\text { Cumulative } \\
\text { Percent }\end{array}$ \\
\hline Age & $20-30$ & 17 & 3.40 & 3.40 \\
& $31-40$ & 181 & 36.20 & 39.60 \\
& $41-50$ & 269 & 53.80 & 93.40 \\
Total & $51-60$ & 33 & 6.60 & 100.00 \\
Marital Status & Married & 500 & 100.00 & \\
& Single & 293 & 58.60 & 58.60 \\
Total & No education & 119 & 41.40 & 100.00 \\
Education & Basic & 258 & 100.00 & \\
& Education & & 51.60 & 75.40 \\
& Secondary & 96 & 19.20 & 94.60 \\
& Education & & & \\
& Tertiary and & 27 & 5.40 & 100.00 \\
\hline Total & above & 500 & 100.00 & \\
\hline
\end{tabular}

As indicated in Table 1, majority of the women engaged in this study were in the 41-50 age group representing as much as $269(53.80 \%)$ of the total response rate. Those who were in the 31-40 age group were represented by 181 (36.20\%) whiles those in the 51-60 age bracket were also represented by $33(6.60 \%)$. Respondents in the age bracket of 20-30 were also represented by $17(3.40 \%)$. It is also evident that most $293(58.60 \%)$ of the respondents were married whiles 207 $(41.40 \%)$ were single. More than half $258(51.60 \%)$ of the respondents have Basic Education and its equivalent. The women client who have Secondary Education and its equivalent were represented by $96(19.20 \%)$ whiles those who have Tertiary Education and above were also represented by 27 (5.40\%).

This is a clear indication that most of the women engaged in this study are within the age brackets of 31-40 and 41-50. This could mean that most of the women clients of MFIs are married and therefore may need the services of MFIs to be empowered to manage their homes. Most of the women engaged in this study also had at least basic education.

\subsection{Microfinance Services and Accessibility}

To determine how well women are able to access microfinance services, the respondents were asked to various questions to elicit responses regarding the kind of services they receive from MFIs, how long they have received such services, the number of times they have received credits and loans as well as the extent to which they have access to such services from MFIs. The responses given by the women have been analysed as follows.

Table 2. Demographic characteristics of the sample.

\begin{tabular}{|c|c|c|c|c|}
\hline Variables & Type & Frequency & Percentage & $\begin{array}{l}\text { Cumulative } \\
\text { Percent }\end{array}$ \\
\hline \multirow[t]{4}{*}{ Services } & Savings & 49 & 9.80 & 9.80 \\
\hline & Loans & 438 & 87.60 & 97.40 \\
\hline & Insurance & 5 & 1.00 & 98.40 \\
\hline & Non-financial & 8 & 1.60 & 100.00 \\
\hline Total & & 500 & 100.00 & \\
\hline \multirow[t]{4}{*}{$\begin{array}{l}\text { Duration } \\
\text { (years) }\end{array}$} & Less than 1 & 23 & 4.60 & 4.60 \\
\hline & $1-3$ & 168 & 33.60 & 38.20 \\
\hline & $3-5$ & 272 & 54.40 & 92.60 \\
\hline & More than 5 & 37 & 7.40 & 100.00 \\
\hline Total & Total & 500 & 100.00 & \\
\hline \multirow[t]{3}{*}{ No. of Times } & $1-3$ times & 71 & 14.20 & 14.20 \\
\hline & $4-6$ times & 292 & 58.40 & 72.60 \\
\hline & More than 6 times & 137 & 27.40 & 100.00 \\
\hline Total & & 500 & 100.00 & \\
\hline
\end{tabular}

From Table 2, it is clear that majority $438(87.60 \%)$ of the women engaged in this study chose Loans as the main service they receive from MFIs. This was followed by those who chose Savings as the main financial services received and they were represented by $49(9.80 \%)$, then those who 
chose insurance who were also represented by $5(1.00 \%)$ of the total response rate. Those who chose non-financial services were also 8 representing $1.60 \%$ out of the total response rate. As indicated in the above table, majority of MFIs women clients have accessed microfinance services for 3 to 5 years representing as much as $272(37.0 \%)$ of the total response rate. This was followed by those whose have received microfinance services for 1 to 3 years who were also represented by 168 (33.60\%). Respondents who have received microfinance services for more than 5 years were represented by $37(7.40 \%)$ whiles those who have received microfinance services for less than 1 year were also represented by $23(4.60 \%)$. The respondents were further asked the number of times they have benefited in that regard from the MFI. Out of 500 respondents, most 292 (58.40\%) of the respondents have taken loans from their MFIs for 4 to 6 times while $137(27.40 \%)$ of them have accessed loans for more than 6 times. The women who have benefited from the MFI in the form of loans for 1-3 times were also 71 also representing $14.20 \%$ out of the total response rate

Table 3. Degree of accessibility to microfinance services.

\begin{tabular}{llll}
\hline Degree & Frequency & Percent & Cumulative Percent \\
\hline Strongly Agree & 164 & 27.30 & 27.30 \\
Agree & 182 & 36.40 & 69.20 \\
Neutral & 45 & 9.00 & 78.20 \\
Disagree & 69 & 13.80 & 92.00 \\
Strongly Disagree & 40 & 8.00 & 100.00 \\
Total & 500 & 100 & \\
\hline
\end{tabular}

Table 3 shows analysis of the categorical responses on the degree of accessibility to microfinance services by the selected women when in need. From the table, most 182 $(36.40 \%)$ of the women agreed they have access to microfinance services when in need. The number of women who strongly agreed they have access to microfinance services when in need were 164 representing $27.30 \%$ of the total response rate whiles those who disagreed that they have access to microfinance services when in need were 69 also representing $13.80 \%$. Women who were neutral about accessibility to microfinance services when in need were 45 $(9.00 \%)$ and those who strongly disagreed were 40 (8.00). This presupposes that majority of the women engaged in this study have access to microfinance services especially when in need.

\subsection{The Impact of Microfinance Accessibility on Women Empowerment}

Two separate regression analyses were conducted on economic and social empowerment resulting from access to microfinance and the results have been presented as flows. In the two separate analyses, three women biographic attributes were used as controlling variables to specifically determine the category of women among whom such empowerment is significant.

\subsubsection{Microfinance Accessibility and Economic Empowerment of Women}

Table 4. Ordered Probit results for estimating the relationship between Microfinance Accessibility and Economic Empowerment of women.

\begin{tabular}{lllll}
\hline $\begin{array}{l}\text { Independent } \\
\text { Variables }\end{array}$ & Coefficient & $\begin{array}{l}\text { Standard } \\
\text { Error }\end{array}$ & z statistics & P value \\
\hline MF & 1.2537 & 0.0625 & 20.07 & 0.000 \\
Age & 0.0094 & 0.1524 & 0.06 & 0.951 \\
Marital Status & -0.4675 & 0.1635 & -2.86 & 0.004 \\
Education & 0.3647 & 0.1621 & 2.25 & 0.024 \\
Observations & & & 500 & \\
Log Likelihood & & & -440.11 & \\
Likelihood Ratio & & & 547.69 & \\
Pseudo R & & & (p-value 0.000) & \\
\hline
\end{tabular}

(a) Dependent Variable: Economic Empowerment

(b) Independent Variable: Microfinance accessibility

(c) Control Variables: Age, Marital status and Education.

Note: $\alpha=0.05, \mathrm{MF}=$ microfinance accessibility, Age $=$ Age of the women, Marital Status = Marital status of the women, Education $=$ Educational background of the women.

Table 4 depicts a Pseudo R-squared value of 0.3836 which considered an excellent fit for a large cross-section data set of 500 women. The probability value of 0.000 for the likelihood ratio also indicates that the explanatory variables used in the probit model are appropriate. From equation (7), the coefficients of the explanatory variables can thus be expressed as follows:

$$
\begin{array}{r}
\mathrm{EE}^{*}=1.2537 \mathrm{MF}+0.0094 \text { Age }-0.4675 \text { Marital }+ \\
0.3647 \text { Education }+\varepsilon_{i}
\end{array}
$$

From equation (10), the independent variable, MF as well as control variables: Age and Education have positive coefficients which indicates that increasing those variables is more likely to cause higher economic empowerment of women. On the contrary, the dummy variable; marital status has a negative coefficient which also implies that those who are married are less likely to be economically empowered from microfinance. Nonetheless, the table indicates that age is insignificant with p-value of 0.951 . The insignificant $\mathrm{z}$ value for Age implies that economic empowerment of women does not depend on age. Therefore, the analysis focuses on Microfinance accessibility as the independent variable and marital status as well as education as the two control variables.

Evident from table 4 is a statistically significant positive coefficient of 1.2537 (p-value of 0.000 ) for dominant explanatory variable, MF which signifies that an increasing access to microfinance is more likely to lead to higher probability of economic empowerment of women. Again, the z-statistic of 20.07 (probability value of 0.0000 ) shows that an increasing access to microfinance leads to greater probability of economic empowerment of women, that is, a greater value in EE as expressed in equation (13).

Another important explanatory variable is the dummy marital status. Given the large $\mathrm{z}$ statistic $(-2.86)$ and the probability value $(0.000)$, it implies that the probability for a 
married woman, all other factors held constant, to be economically empowered from microfinance programs is small. This also implies that among the microfinance women clientele, those married are less likely to be empowered economically than those who are not married. This is also supported by a negative coefficient of -0.4675 and a p-value of 0.000 .

From the table Education is also another significant explanatory variable. A positive coefficient of 0.3647 (pvalue of 0.000 ) implies that a higher education level among women is more likely to warrant higher economic empowerment of women. Also, with the corresponding large $\mathrm{z}$ statistic (2.25), the probability for women with higher education, all other factors held constant, to be economically empowered from microfinance programs is greater. This also implies that among the microfinance women clientele, those with higher education are more likely to be empowered economically than those who are not educated.

The supports the findings of Kabeer (2001) who in his study on women empowerment established that women's accessibility to microfinance was significant determinant of the magnitude of economic contributions reported by women; of the likelihood of an increase in asset holdings in their own names; of an increase in their exercise of purchasing power especially among women who are not married or have limited responsibilities at home [42]. This also confirms the findings Laha and Kuri (2001) who found that states having higher level of microfinance programs in Indian are also the states with a relatively high level of economic empowerment of women especially where those women have attained at least basic education [11].

\subsubsection{Microfinance Accessibility and Social Empowerment of Women}

Table 5. Ordered Probit results for estimating the relationship between Microfinance Accessibility and Social Empowerment of women.

\begin{tabular}{lllll}
\hline $\begin{array}{l}\text { Independent } \\
\text { Variables }\end{array}$ & Coefficient & $\begin{array}{l}\text { Standard } \\
\text { Error }\end{array}$ & z statistics & P value \\
\hline MF & 0.8735 & 0.0517 & 16.88 & 0.000 \\
Age & -0.4332 & 0.1465 & -0.30 & 0.768 \\
Marital Status & 0.7274 & 0.1564 & 4.65 & 0.000 \\
Education & 0.5640 & 0.1530 & 3.69 & 0.000 \\
Observations & & & 500 & \\
Log & & & -538.55 & \\
Likelihood & & & 357.89 & \\
Likelihood & & & (p-value 0.000$)$ & \\
Ratio & & & 0.2494 & \\
Pseudo $\mathrm{R}^{2}$ & & &
\end{tabular}

(a) Dependent Variable: Social Empowerment

(b) Independent Variable: Microfinance accessibility

(c) Control Variables: Age, Marital status and Education.

Note: $\alpha=0.05, \mathrm{MF}=$ microfinance accessibility, Age $=$ Age of the women,

Marital Status $=$ Marital status of the women, Education $=$ Educational background of the women.

From Table 5, Pseudo R-squared value of 0.2494 is considered good fit for a large cross-section data set of 500 women. The probability value of 0.000 for the likelihood ratio also indicates that the explanatory variables used in the probit model are appropriate. The coefficients of the explanatory variables can be substituted into equation (8) to estimate equation (11) as follows:

$$
\begin{gathered}
\mathrm{SE}^{*}=0.8735 M F-0.4332 \text { Age }+0.7472 \text { Marital }+ \\
0.5640 \text { Education }+e_{i}
\end{gathered}
$$

From equation (11), the independent variable, MF as well as control variables: Marital status and Education have positive coefficients which indicates that increasing those variables is more likely to warrant higher social empowerment of women. On the other hand, Age has a negative coefficient which also implies that increase in age is less likely to warrant social empowerment among women. However, the table indicates that age is insignificant with pvalue of 0.768 . The insignificant $\mathrm{z}$ value for Age implies that social empowerment of women does not depend on age.

An examination of Table 5 indicates that $\mathrm{MF}$ is the dominant explanatory variable with a positive coefficient of 0.8735 (p-value of 0.000 ) indicating an increasing access to microfinance is more likely to lead to higher probability of social empowerment of women. Again, the z-statistic of 16.88 (probability value of 0.0000 ) shows that an increasing access to microfinance leads to greater probability of social empowerment of women, that is, a greater value in $\mathrm{SE}$ as expressed in equation (12).

Another important explanatory variable is the dummy marital status. Given the large $\mathrm{z}$ statistic (4.65) and the probability value $(0.000)$, it implies that the probability for a married woman, all other factors held constant, to be socially empowered from microfinance programs is greater. This also implies that among the microfinance women clientele, those married are more likely to be socially empowered than those who are not married. This is also buttressed by a positive coefficient of 0.7274 and a p-value of 0.000 .

From the table Education is also another significant explanatory variable. A positive coefficient of 0.5640 (pvalue of 0.000 ) means that, a higher education level among women is more likely to warrant higher social empowerment of women. Also, with the corresponding large $\mathrm{z}$ statistic (3.69), it implies that the probability for women with higher education, all other factors held constant, to be socially empowered from microfinance programs is greater. This also implies that among the microfinance women clientele, those with higher education are more likely to be empowered than those who are not educated.

The findings of this study does not differ from the research findings of Khan and Noreen (2012) the role of microfinance in empowerment of women in Pakistan finds that access to credit through microfinance organisations has a positive impact on social empowerment of women and also that loan utilization by the woman herself is of importance especially married women. They further brought to fore that access to microfinance can empower women to commit themselves to children's education, become more confident, more assertive, more likely to take part in family and community decisions and better able to confront gender inequities [43]. The analysis in this study also confirms the findings of Leach et 
al. (2002) who also found that microfinance services have succeeded in socially empowering women where economic empowerment could not be possible due to lack of knowledge and understanding about business among women [49].

\subsection{Problems Women Encounter in Accessing Microfinance Services}

Again, the women were asked whether they have any problem in accessing microfinance services and some problems were given by the women engaged in this study. The responses given by the women on the problems they encounter in accessing loans have been summarized in the table below.

Table 6. Problems women encounter in accessing microfinance services.

\begin{tabular}{llll}
\hline Problems & Frequency & Percent & $\begin{array}{l}\text { Cumulative } \\
\text { Percent }\end{array}$ \\
\hline Collateral required for loans & 118 & 23.60 & 23.60 \\
Service application procedures & 99 & 19.80 & 43.30 \\
Lack of business education for clients & 87 & 17.40 & 60.80 \\
High interest rate on loans & 196 & 39.20 & 100.00 \\
Total & 500 & 100 & \\
\hline
\end{tabular}

As indicated in the above table, majority 196 (39.20\%) of the respondents in this study high interest on loans as the problem encountered in accessing loans. Women who see Collateral for loans as a problem represented by 118 $(23.60 \%)$ whiles those who see service application procedures as a problem were also 99 representing $19.80 \%$ of the total response rate. Women who see lack of business education as a problem in microfinance accessibility were also represented by $87(17.40 \%)$. This is a clear indication that the predominant problem faced by majority of the women in accessing microfinance services is high interest rate on loans.

\section{Conclusion}

In Ghana, the government has developed several policies to enhance microfinance to simultaneously empower women and alleviate poverty. However, there has been a hot debate on the potency of microfinance in empowering the Ghanaian women because loan given to women is controlled by men and also Microfinance Institutions (MFIs) are extorting money from poor women through very high interest rates just like the money lenders, and also lead to many women running away from their homes and villages after failure of repayment of loan instalment avoiding their properties to be taken by MFIs. As a result, this research was conducted to analyse the impact of microfinance programs on the economic and social empowerment of women in Ghana and to also establish the relationship between economic and social empowerment of women resulting from their participation in microfinance programs.

The findings of this study posit that an increasing access to microfinance is more likely to lead to higher probability of economic empowerment of women as well as higher probability of women social empowerment. This study also establishes that the significance of such relationship is dependent marital status and education of the women whiles age has no impact on both economic and social empowerment of women resulting from microfinance. This means that among the microfinance clientele, marital status and education level of the respondents are the two women demographic attributes that affect women empowerment apart from accessibility to microfinance. Furthermore, it is evident in this study that women encounter some problems in accessing microfinance services: high interest rate on loans; collateral required for loans; cumbersome service application procedures and lack of business education for women of which high interest rate is paramount. Despite the problems women encounter in accessing microfinance services, microfinance still contributes significantly to the economic and social empowerment of women in Ghana particularly among the women who have basic education and above. Therefore, it is very crucial for GoG, policy makers and MFIs to device strategies to specifically surmount problems Ghanaian women encounter in accessing microfinance and also increase microfinance outreach programmes especially among the rural women since enhanced microfinance accessibility could be a perfect tool to accelerate economic and social empowerment of women in Ghana.

\section{Recommendations}

The study revealed that the women clientele have been empowered through microfinance in several ways; however, there exist myriad problem militating against the succinct empowerment of these women through microfinance. The following recommendations have therefore been made to help package microfinance to be a perfect tool for women empowerment.

The study revealed that although women face several problems in accessing microfinance services, the paramount among those problems is the high rate of interest on loans. It is therefore recommended that the interest charged on loans be reduced to encourage existing women's patronization and even attract new customers since the ultimate goal of most women clienteles of MFIs is to have access to loans. The GoG could enforce a maximum lending rate on loans above which MFIs cannot lend loans to their clients. This will help MFIs satisfy the need for sustainability of their institutions and at the same times relieve these women from exploitation resulting from high interest rate on loans.

The study also revealed that another problem women encounter in microfinance is their lack of business knowledge. Microfinance programs should therefore factor basic business education to train these women on basic business management.

The study concludes that enhanced microfinance accessibility improves both economic and social empowerment of women with significant reference to marital status and education of women. As a result, it is recommended that $\mathrm{GoG}$ and policy makers increase 
microfinance outreach programs particularly among the poor women whiles addressing the problems inherent in microfinance accessibility to these women while paying much attention to the marital status and education level of the target women.

The study suggests that further research be engineered to consider microfinance related issues such as microfinance sustainability and mission-drift among MFIs and how those issues affect economic and social empowerment of women especially in Ghana.

\section{References}

[1] Rahman, R. \& Nie, Q. The synthesis of Grameen bank microfinance approaches in Bangladesh. International. Journal of Economics and Finance 3, p. 207 (2011).

[2] Selinger, E. Does microcredit 'empower'? Reflections on the Grameen Bank debate. Humun Studies 31, 27-41 (2008).

[3] Cull, R., Demirgüç-kunt, A. \& Morduch, J. Financial performance and outreach: A global analysis of leading microbanks. The Economic Journal 117, 107 - 133 (2007).

[4] World Bank Group \& World Bank. World Development Indicators 2014. Group 1-26 (2014).

[5] Botchway, K. Paradox of empowerment: Reflections on a case study from Northern Ghana. World Development. 29, 135-153 (2001).

[6] Boateng, G. O. et al. Women's empowerment in the context of Millennium Development Goal 3: A case study of married women in Ghana. Social Indicators Research 115, 137-158 (2014).

[7] Annim, S. K. Targeting the Poor Versus Financial Sustainability and External Funding: Evidence of Microfinance Institutions in Ghana. Journal of Development Entrepreneurship 17, 1250016 (2012).

[8] Adjei, J., Arun, T. \& Hossain, F. Asset building and poverty reduction in Ghana: The case of microfinance. Savings Development 33, 265-292 (2009).

[9] Oteng-abayie, E. F., Amanor, K. \& Frimpong, J. M. The Measurement and Determinants of Economic Efficiency of Microfinance Institutions in Ghana: A Stochastic Frontier Approach. African Review of Economics and Finance 2, 149$166(2011)$.

[10] Van Rooyen, C., Stewart, R. \& de Wet, T. The Impact of Microfinance in Sub-Saharan Africa: A Systematic Review of the Evidence. World Development 40, 2249-2262 (2012).

[11] Laha, A. \& Kuri, P. K. Measuring the Impact of Microfinance on Women Empowerment: A Cross Country Analysis with Special Reference to India. International Journal of Public Admimistration 37, 397-408 (2014).

[12] Hartarska, V. \& Nadolnyak, D. An Impact Analysis of Microfinance in Bosnia and Herzegovina. World Development. 36, 2605-2619 (2008).

[13] Abiola, B. Impact Analysis of Microfinance in Nigeria. International Journal of Economics and Finance 3, 217-226 (2011).
[14] Corsi, M., Botti, F., Rondinella, T. \& Zacchia, G. Women and Microfinance in Mediterranean Countries. Development 49, 67-74 (2006).

[15] Adams, D. W. \& Vogel, R. C. Microfinance approaching middle age. Enterprise Developemnt and Microfinance 25, 103-115 (2014).

[16] Brau, J. C. \& Woller, G. M. Microfinance: A comprehensive review of the existing literature. Journal of Entrepreneural Finance 9, 1-27 (2004).

[17] Beisland, L. \& Mersland, R. The Use of Microfinance Services Among Economically Active Disabled People: Evidence from Uganda. Journal of International Development 83, 80-90 (2012).

[18] Nourse, T. H. The missing parts of microfinance: Services for consumption and insurance. SAIS Review International Affairs 21, 61-69 (2001).

[19] Dary, S. K. \& Issahaku, H. Exploring Innovations in Microfinance Institutions in Northern Ghana. Business and. Economic Reearch. 3, 442-460 (2013).

[20] Togba, E. L. Microfinance and households access to credit: Evidence from Cote d'Ivoire. Structural Change and Economic Dynamics 23, 473-486 (2012).

[21] Ahmed, S. Microfinance institutions in Bangladesh: achievements and challenges. Financial Management 35, 999-1010 (2009).

[22] Nasir, S. Microfinance in India: Contemporary Issues and Challenges. Middle-East Journal of Scientific Research 15, 191-199 (2013).

[23] Schicks, J. Microfinance Over-Indebtedness : Understanding its drivers and challenging the common myths Microfinance Over-Indebtedness: and challenging the common myths. African fianace Journal 32, 33 (2010).

[24] Cull, R., Demirgüç-kunt, A. \& Morduch, J. Microfinance Tradeoffs: Regulation, Competition, and Financing. Handbook of microfinance 141- (2011).

[25] Kono, H. \& Takahashi, K. Microfinance revolution: Its effects, innovations, and challenges. Developing Economies 48, 15-73 (2010).

[26] Woldie, A., Isaac Mwita, J. \& Saidimu, J. Challenges of microfinance accessibility by SMEs Tanzania. International Business Review 54, 567-579 (2012).

[27] Mosedale, S. Policy arena Assessing women's empowerment: Towards a conceptual framework. Journal of International Development 17, 243-257 (2005).

[28] Kabeer, N. Is Microfinance a 'Magic Bullet' for Women's Empowerment? Analysis of Findings from South Asia. Economic and Political Weekly 40, 4709-4718 (2005).

[29] Weber, O. \& Ahmad, A. Empowerment through microfinance: The relation between loan cycle and level of empowerment. World Develpoment. 62, 75-87 (2014).

[30] Reji, E. M. Microfinance and Women Empowerment A General Framework for Assessment of Women Empowerment. Indian Journal of Social Work 70, 557-570 (2009). 
[31] Chowdhury, S. S. \& Chowdhury, S. A. Microfinance and Women Empowerment: A Panel Data Analysis Using Evidence from Rural Bangladesh. International Journal of Economics and Finance 3, 86-96 (2011).

[32] Ngo, T. M. P. \& Wahhaj, Z. Microfinance and gender empowerment. Journal of Development Economics 99, 1-12 (2012).

[33] Sutton-brown, C. Women's Empowerment in the Context of Microfinance: A Photovoice Study. Policy Studies 1-147 (2011).

[34] Skarlatos, K. Microfinance and Women's Economic Empowerment: Bridging the Gap, Redesigning the Future. Spring (2004).

[35] Mayoux, L. Tackling the Down Side: Social Capital, Women's Empowerment and Micro-Finance in Cameroon. Development and Change 32, 435-464 (2001).

[36] Sanyal, P. From Credit to Collective Action: The Role of Microfinance in Promoting Women's Social Capital and Normative Influence. American Social Review 74, 529-550 (2009).

[37] Maclean, K. Capitalizing on women's social capital? Womentargeted microfinance in Bolivia. Development and Change $41,495-515$ (2010).

[38] Dalal, K., Shabnam, J., Andrews-Chavez, J., Mårtensson, L. B. \& Timpka, T. Economic empowerment of women and utilization of maternal delivery care in Bangladesh. International Journal of Preventive Medicine 3, 628-636 (2012).

[39] OECD. Women's economic empowerment. GENDERNET 129 (2012).
[40] Marinova, J. Empowerment of Women in Bulgaria. Development 53, 193-195 (2010).

[41] Chronister, K. M. \& McWhirter, E. H. Applying social cognitive career theory to the empowerment of battered women. Journal of Counselling and Development 81, 418425 (2003).

[42] Kabeer, N. Discussing Women's Empowerment. SIDA Studies $136(2001)$

[43] Littlefield, B. Y. E., Morduch, J. \& Hashemi, S. Is Microfinance an Effective Strategy to Reach the Millennium Development Goals ? Focus Note 24, 1-11 (2003).

[44] Neuman, W. L. "Social Research Methods-Quantitative and Qualitative Approaches". 6th Edition, Pearson Education, Inc. USA (2006).

[45] Zikmund, Z. W. Business Research Methods. 6th edition. London: Dryden (2002).

[46] Hair, J., Bush, R. and Ortinau, D., Marketing research: Within a changing environment (3rd ed.). New York: McGraw-Hill (2006).

[47] Vytlacil, E., 2006. “Ordered Discrete Choice Selection Models and Local Average Treatment Effect Assumptions: Equivalence, Nonequivalence and Representation Results," Review of Economics and Statistics, 88, pp. 578-581.

[48] McElvey, R. and Zavoina, W. "A Statistical Model for the Analysis of Ordered Level Dependent Variables," Journal of Mathematical Sociology, 4, pp. 103-120, (1975).

[49] Leach, F. \& Sitaram, S. Microfinance and women's empowerment: a lesson from India. Development in Practice (2002). 